IZA DP No. 618

Oligopsony, Institutions and the Efficiency of General Training

Alison L. Booth

Marco Francesconi

Gylfi Zoega

October 2002 


\title{
Oligopsony, Institutions and the Efficiency of General Training
}

\author{
Alison L. Booth \\ Australian National University, University of Essex \\ and IZA Bonn \\ Marco Francesconi \\ University of Essex and IZA Bonn
}

Gylfi Zoega

Birkbeck College, University of London

Discussion Paper No. 618
October 2002

\author{
IZA \\ P.O. Box 7240 \\ D-53072 Bonn \\ Germany \\ Tel.: +49-228-3894-0 \\ Fax: +49-228-3894-210 \\ Email: iza@iza.org
}

This Discussion Paper is issued within the framework of IZA's research area Evaluation of Labor Market Policies and Projects. Any opinions expressed here are those of the author(s) and not those of the institute. Research disseminated by IZA may include views on policy, but the institute itself takes no institutional policy positions.

The Institute for the Study of Labor (IZA) in Bonn is a local and virtual international research center and a place of communication between science, politics and business. IZA is an independent, nonprofit limited liability company (Gesellschaft mit beschränkter Haftung) supported by the Deutsche Post AG. The center is associated with the University of Bonn and offers a stimulating research environment through its research networks, research support, and visitors and doctoral programs. IZA engages in (i) original and internationally competitive research in all fields of labor economics, (ii) development of policy concepts, and (iii) dissemination of research results and concepts to the interested public. The current research program deals with (1) mobility and flexibility of labor, (2) internationalization of labor markets, (3) welfare state and labor market, (4) labor markets in transition countries, (5) the future of labor, (6) evaluation of labor market policies and projects and (7) general labor economics.

IZA Discussion Papers often represent preliminary work and are circulated to encourage discussion. Citation of such a paper should account for its provisional character. A revised version may be available on the IZA website (www.iza.org) or directly from the author. 


\section{ABSTRACT \\ Oligopsony, Institutions and the Efficiency of General Training*}

In oligopsonistic labour markets, firms have some market power, and a wedge is created between wages and marginal product. When oligopsonistic firms' production technology requires generally trained workers, firms may therefore receive part of the returns to general training and be willing to pay for it despite its general nature. However this outcome is not efficient, in the sense that too few workers are trained and workers who are hired receive too little training. We consider how different institutions can affect this inefficiency. Industry-level minimum wages can remove the training inefficiency and provide workers with the right incentives to invest in general training. A training subsidy to firms can also be used to achieve first-best. Trade unions might also remedy the market failure, in two ways. First, if an industry-wide union has a direct say in the training decision and maximises the utility of a representative worker, it will choose the efficient level of training intensity. Second, firmspecific unions, through raising relative wages and reducing turnover, can increase training intensity.

JEL Classification: $\quad$ E32, J23, J24, J54

Keywords: training, oligopsony, unions, minimum wages

Corresponding author:

Alison Booth

Economics Program, RSSS

Australian National University

Canberra ACT 0200

Australia

Tel.: +61261253285

Fax: +61261250182

Email: albooth@essex.ac.uk

\footnotetext{
* Financial support from the Leverhulme Trust (Award F/00213C "Work-related Training and Wages of Union and Non-union Workers in Britain") and the Economic and Social Research Council is gratefully acknowledged. For their helpful comments, we are grateful to V. Bhaskar, Ken Burdett, Melvyn Coles, Abhinay Muthoo and seminar participants at the University of Essex, the Australian National University, the London School of Economics, and Leicester University.
} 



\section{Introduction}

In this paper we present a simple model of oligopsonistic wage determination in an economy in which workers require general training. Our analysis is motivated by empirical evidence on a positive correlation between trade union presence and work-related training, and which represents a challenge to the competitive labour market model. The predictions of our model are consistent with much of this empirical evidence. ${ }^{1}$

We assume, in common with much of the recent training literature, that employers have some market power in the setting of wages. ${ }^{2}$ Like Bhaskar, Manning and To (2002), we define oligopsony as being a situation in which employer market power persists despite competition with other employers. There are many approaches to modeling such market power. The particular approach that we adopt is of idiosyncratic match quality, as will be explained below, and thus some workers randomly change employer after they have been trained. Because of firms' market power, there is a wedge between wages and marginal product and the incentives for workers to invest efficiently in general training are distorted, as we show in the first half of our paper. Although firms' oligopsony power means that they receive part of the returns to general training and might therefore be willing to pay for it, there is no guarantee that this will be at the efficient level. ${ }^{3}$ For this reason, it is interesting to see if particular labour market institutions can be thought of as a second-best remedy to overcome the problem of under-investment in general training, and this is what we investigate in the second half of our paper. An important new result

\footnotetext{
${ }^{1}$ Microeconometric studies show that unionised workers are significantly more likely to receive workrelated training than non-unionised ones (see for example Booth, 1991; Lynch, 1992; Green, Machin and Wilkinson, 1999; Booth, Francesconi and Zoega, 2001). Cross-country comparisions also reveal that workers in Europe receive more work-related training than their counterparts in the United States (see for example OECD, 1995).

${ }^{2}$ See for example Stevens (1994, 1996), Chang and Wang (1996), Malcomson, Maw and McCormick (1997), Booth and Chatterji (1998), Acemoglu and Pischke $(1998,1999)$ and Booth and Zoega (1999). In their survey of oligopsony in the labour market, Bhaskar, Manning and To (2002) also argue that many otherwise puzzling labour market phenomena (such as wage dispersion and racial pay gaps) can be explained by the assumption that firms have some market power in wage setting.

${ }^{3}$ See Acemoglu and Pischke (1999) who also provide references to evidence of firms' financing general training.
} 
arises from our analysis: we show that minimum wages and labour unions can help reduce and sometimes overcome a market failure in the provision of on-the-job training. The predictions of our model are consistent with much of the available empirical evidence. Training subsidies to firms can also be used to achieve the optimal levels of training.

Our approach has implications for the trade union literature, which we extend in two ways. First, we model an alternative avenue through which unions have the potential to enhance efficiency — through negotiation of training as well as wages — that is distinct from the usual ways discussed in the union literature. Evidence that unions do bargain over both wages and training intensity is provided in, for example, Mahnkopf (1992) and Streek (1989). Second, we extend the existing literature on union bargaining structures (see for example Calmfors and Driffill, 1988; and Dowrick, 1989) by investigating how the choice of bargaining level — centralised versus decentralised - might affect wages and training outcomes. ${ }^{4}$

In the next section, we outline the structure of the model and its underlying assumptions. In Section 3, we consider wage and training decisions made by firms when they are unconstrained by any institutional rigidities in the labour market — what we term the benchmark case. We also show that the firm is willing to finance the general training that it provides to workers. In Section 4 we then compare this sub-optimal 'benchmark' outcome with the first-best level of hiring and training per worker. This amounts to assuming that there is a social planner who can internalise the training externalities by choosing the number of trainees and their training intensity to maximise the social returns from training. We show that the benchmark case generates the two types of training inefficiency: (i) too few workers are hired into the training sector, and (ii) those workers who are hired receive too little training. In Section 5, we suggest that an ap-

\footnotetext{
${ }^{4}$ Most theoretical models of union wage and employment determination typically assume only one union and firm, thereby side-stepping analysis of the impact of the level at which bargaining occurs. And yet unionised industrial economies exhibit a variety of bargaining structures and varying degrees of coordination, which are likely to have an impact on macroeconomic outcomes — as emphasized in Flanagan (1999) — as well as microeconomic outcomes.
} 
propriately set minimum wage at the sectoral level can remove these inefficiencies. An alternative policy might be a training subsidy to firms. In Section 6, we compare the first-best and benchmark outcomes with that pertaining in a unionised labour market. We show that unions can increase social welfare by increasing training intensity, while reducing welfare by reducing the number of workers trained. ${ }^{5}$ Thus unions, while having the standard adverse effect on employment, can in other respects be welfare improving. Section 7 concludes.

\section{Assumptions}

There is Bertrand competition between two identical firms, $i=1,2$, and there are two periods. There is a perfectly elastic supply of workers willing to be hired into the training sector at the start of Period 1. ${ }^{6}$ During the initial period, workers who are hired receive training in work-related skills that are general to both firms in the sector. The production technology used by both firms is characterized by constant returns, but firms' profit functions are concave owing to the training technology. Throughout we shall consider only symmetric pure strategy equilibria.

Each firm determines how many workers it wishes to train, sets a wage schedule and decides on the level of training per worker. Remuneration is lower in the training period but higher in the post-training period, as will be explained below. The extent to which remuneration is lowered in Period 1 depends on how much time workers spend in training, which also determines the extent to which post-training productivity and wages are augmented in Period 2.

At the start of Period 2, trained workers may choose either to stay with the firm that provided the training and produce, or quit to work in the other firm in the sector.

\footnotetext{
${ }^{5}$ Our model differs from that of Booth and Chatterji (1998) who consider how a labour union might affect the number of workers trained where training comprises both specific and general elements. They show how a union acts to reduce the hold-up problem that arises if firms have some monopsony power and labour contracts are not legally enforceable.

${ }^{6}$ Wages and productivity in the alternative sector are assumed zero for simplicity.
} 
Workers once trained do not leave the skilled sector. The retention probability for each firm is a function of the wage differential between the two firms and individual workers' stochastic preferences. Thus the labour supply curve facing each firm in period 2 is upward sloping. For simplicity, we do not model layoffs in the face of product-market uncertainty. ${ }^{7}$ Because some trained workers may quit, in Period 2 each firm will produce using some internally-trained and some externally-trained workers.

\subsection{Training and training costs}

We make the plausible assumption that there are two types of training and training costs. The first reflects induction training (such as in industry health and safety), which has an impact on the number of initial hires into the industry but leaves individual productivity unaffected. Thus at the start of Period 1, each firm hires and instantaneously inducts workers at the cost of $c\left(N_{i}\right)$, where $N_{i}$ is the number of workers trained by firm $i, i=1,2$, and $c^{\prime}>0$ and $c^{\prime \prime}>0$. The convexity reflects diseconomies of scale in teaching through, for example, the firm hitting constraints of capital equipment required for training as the number of trainees increases. While this induction cost plays a crucial role in determining the number of workers each firm will hire, it does not affect the amount of general training each worker will receive once hired.

Second, each worker hired in Period 1 receives general training in formal courses. The amount of this training per worker - what we term training intensity - is endogenous. Given a finite length to the working week, the opportunity cost of time spent in formal courses is foregone production. Consequently this type of training affects each worker's productivity in both periods. More formally, during Period 1, workers spend a fraction $\phi$ of their time taking courses to acquire further general training, where $0 \leq \phi \leq 1$, and then spend the remaining fraction of their time $(1-\phi)$ in production. Thus $\phi$ denotes training intensity. This corresponds to a stylized form of apprenticeship training, where

\footnotetext{
${ }^{7}$ See Eguchi (2002) who models layoffs and in which an additional role emerges for trade unions as commitment devices under contractual incompleteness.
} 
apprentices spend a proportion of the working week in formal courses and the remainder of their time on the job producing. Articled clerks are another example of this form of training.

Each worker has productivity corresponding to one diminished labour unit $(1-\phi)$ in Period 1, and $g(\phi)$ augmented labour units in Period 2, where $g(\phi)$ is a continuous strictly concave differentiable function with $g^{\prime}(1)=0$ and $g^{\prime}(0)=\infty$, and we impose the normalisation that $g(\phi) \geq 1$. The concavity of $g$ reflects diminishing returns to training intensity, an assumption that is supported by survey evidence. ${ }^{8}$ Let $v$ denote units of output prior to any augmentation by training and assume this is the same for all individuals ( $v$ might also be conceptualized as a worker's innate productivity). It follows that output per labour unit is $(1-\phi) v$ in Period 1 and $g(\phi) v$ in Period 2.

\subsection{The retention probability}

We assume that workers with identical skills and abilities have heterogeneous subjective preferences over the non-wage characteristics of employers. This heterogeneity in preferences gives firms a degree of market power over their workforce, as will be demonstrated in the following sections. These preferences are not known ex ante but are revealed while working at the firm. This assumption is analogous to that made by, inter alia, Stevens (1994, 1996) and Bhaskar and To (2001), and is a simple way of characterizing imperfect competition in the labour market, as discussed by Bhaskar, Manning and To (2002). Empirical support for this assumption is given in McCue and Reed (1996). This heterogeneity is the only source of uncertainty in our model.

We capture this heterogeneity in preferences over the non-wage characteristics of employers by assuming stickiness in the movement of workers between firms. Thus the retention probability (the probability that workers will not quit after training) is a function not only of the wage differential between the two firms but also contains a

\footnotetext{
${ }^{8}$ See for example Booth, Francesconi and Zoega (2001).
} 
stochastic component.

Following Stevens (1994, 1996:32), we denote the retention probability — illustrated in Figure 1 - by $F(x) \in[0,1]$, where $x=\omega_{1}-\omega_{2}$ is the difference in wage rates between Firms 1 and 2 and $F^{\prime}(x) \geq 0 \forall x$. We assume the probability density is symmetric about zero, so that $F(-x)=1-F(x)$. In industry equilibrium we have $x=\omega_{1}-\omega_{2}=0$ and $F(0)=\frac{1}{2}$. This implies that half the original workforce is retained. ${ }^{9}$ Hence, half the Period 2 workforce is internally trained and half trained elsewhere. Furthermore, we assume that as $x \rightarrow \infty, F(x) \rightarrow 1, F^{\prime}(x) \rightarrow 0$, and as $x \rightarrow-\infty, F(x) \rightarrow 0$ and $F^{\prime}(x) \rightarrow 0$.

\section{[Insert Figure 1 near here]}

If workers were perfectly loyal, we would have $F(x)=1 \forall x$. We will see below that the source of the market failure, and the reason why minimum wages or unions can play a remedial role if training intensity is on the bargaining agenda, lies in $F(0)<1$.

\subsection{Timing in the model}

Unskilled workers are trained in Period 1, during which time they can both produce and undergo formal training, where the amount of formal training is endogenous. In period 2, trained workers either remain with the training firm and produce output or quit to the other firm, depending on their heterogeneous preferences for the non-wage characteristics of firms. The timing is shown in Figure 2.

\footnotetext{
${ }^{9}$ This assumption is for tractability and convenience only. Other distributions would generate similar results provided only that some positive fraction of workers are retained at each firm.
} 
Figure 2: The Ordering of Decisions

\section{Period 1}

A. Firms each set wages, training intensity $\phi_{i}$ and new hires $N_{i}$ and incur induction $\operatorname{costs} c\left(N_{i}\right)$.

B. Workers spend $\phi$ of their time in courses and $(1-\phi)$ in production.

C. Workers learn of their match quality over this period.

\section{Period 2}

A. At each firm, $F N_{i}$ workers stay while $(1-F) N_{i}$ workers leave.

B. Each firm then produces with a workforce comprising retained workers

plus trained workers "poached" from the other firm.

\section{The Benchmark Case}

The training sector comprises two identical firms. Each firm takes the other firm's actions as given, and chooses training intensity $\phi_{i}$, wages $\omega_{i}$, and employment $N_{i}$ in order to maximise profits. The expected profits of firm $i, i=1,2$, are

$$
P_{i}=\left(1-\phi_{i}\right)\left(v-\omega_{i}\right) N_{i}+R F(x)\left(v-\omega_{i}\right)\left[g\left(\phi_{i}\right) N_{i}+g\left(\phi_{j}\right) N_{j}\right]-c\left(N_{i}\right)
$$

where $v$ is the (inherent) productivity of a worker (which is independent of the total number of workers employed), $N_{i}$ is the number of workers hired by firm $i, \omega_{i}$ denotes the wage rate paid by firm $i$ and $R$ is the exogenous discount factor. The first term in equation (1) represents the Period 1 profits from employing workers, while the second term represents the discounted expected profits in Period 2 from employing skilled workers, where $R$ is the discount rate. The final term is the cost of giving the $N_{i}$ work- 
ers induction training. The $i$-th firm will produce in Period 2 using retained internally trained workers plus externally trained workers who quit the other firm. ${ }^{10}$

Notice in equation (1) that the remuneration actually received by a worker is the wage rate multiplied by $(1-\phi)$ in Period 1 and augmented by $g(\phi)$ in Period $2 .{ }^{11}$ Analogously a worker's innate productivity $v$ is multiplied by $(1-\phi)$ while undergoing training in Period 1 and augmented by $g(\phi)$ in Period 2. (In Appendix A, we demonstrate the robustness of our results to allowing $\omega_{i}$ to vary across time-periods. Since this adds to the complexity of the model without generating additional insights, we continue in the main text with the assumption that $\omega_{i}$ is invariant to time.) Worker remuneration differs across time periods, however, because the remuneration actually received by a worker is given by $(1-\phi) \omega_{1}$ in Period 1 and $g(\phi) \omega_{1}$ in Period 2.

The first-order conditions for the $i$-th firm — which we now call Firm 1 - with respect to $\phi, \omega$ and $N$ follow. ${ }^{12}$ We start with the first-order condition with respect to the training intensity $\phi$ :

$$
\phi_{1}: R F(x) g^{\prime}\left(\phi_{1}\right)=1
$$

which says that the marginal benefit of increasing training intensity - in terms of the expected discounted second-period return - should be set equal to the marginal cost which is the sacrificed output in Period 1. Wage rates are also set optimally:

$$
\omega_{1}:\left(1-\phi_{1}\right) N_{1}=\left[R g\left(\phi_{1}\right) N_{1}+R g\left(\phi_{2}\right) N_{2}\right]\left\{\left(v-\omega_{1}\right) F^{\prime}(x)-F(x)\right\}
$$

The left-hand side term and the term in squiggly brackets on the right-hand side denote the marginal cost of increasing wages — which take the form of higher wage

\footnotetext{
${ }^{10}$ Firm $i$ 's retention probability for the $N_{i}$ workers trained by that firm is $F(x)$, while firm j's retention probability for the $N_{j}$ workers that it trains is given by $F(-x)$. We use the symmetry properties of $F$, viz. $F(-x)=[1-F(x)]$ to obtain the expression in $(1)$.

${ }^{11}$ Thus two period remuneration is $[(1-\phi+g(\phi)] \omega$. Clearly, for the firm to attract any workers, this must always be non-negative (since the alternative sector wage is set to zero in both periods).

${ }^{12}$ The second-order conditions for a maximum are satisfied, since the Hessian matrix is negative definite.
} 
payments in both periods to workers who would have been retained and poached anyway. The term in square brackets on the right-hand side refers to the marginal benefit — profits due to extra retention and recruitment. Finally, we have a condition for the optimal level of employment:

$$
N_{1}:\left[\left(1-\phi_{1}\right)+R F(x) g\left(\phi_{1}\right)\right]\left(v-\omega_{1}\right)=c^{\prime}\left(N_{1}\right)
$$

The left-hand side term represents the marginal benefit of increasing employment this is expected discounted profits per worker for the two periods - and the right-hand side denotes the marginal cost, which is the cost of giving a new worker the induction training at the beginning of Period 1.

Notice that, given our assumed constant returns production function, the intensity of training, on the one hand, and both wages and the number of workers hired, on the other hand, are separable because the costs and benefits from acquiring on-the-job training do not depend on wages and the number of workers hired. Due to our chosen specification, both higher wages and higher employment reduce the marginal benefit and the marginal cost of training equally, and hence do not affect the firm's training intensity decision.

Given symmetry, in industry equilibrium, $\omega_{1}=\omega_{2}$. (The proof of this is given in Appendix B.) It also follows that in equilibrium

$$
R F(0) g^{\prime}\left(\phi_{1}\right)=1=R F(0) g^{\prime}\left(\phi_{2}\right)
$$

so that training intensity is the same across firms in equilibrium.

Proposition 1. Labour market stickiness, characterised by properties of the retention probability function $F(x)$, drives a wedge between marginal productivity and the wage rate, and gives some market power to the firm. 
Consider Firm 1 only, since the equilibrium is symmetric. We obtain from manipulation of the first-order conditions: ${ }^{13}$

$$
\omega_{1}=v-\frac{F(0)}{F^{\prime}(0)}\left[1+\frac{g^{\prime}(\phi)(1-\phi)}{2 g(\phi)}\right] .
$$

The equation embodies equations (2) and (3) and so implies that the marginal profits from increasing training intensity $\phi_{1}$ and wages $\omega_{1}$ are both equal to zero. Note that $\omega_{1}$ is invariant to the number of trainees, given the assumed form of our production function. The term $\frac{F(0)}{F^{\prime}(0)}$ measures the degree of monopsony power of the firm.

There are several things to note from equation (6). First, in the limit, as $F^{\prime}(0) \rightarrow \infty$, $\omega_{1} \rightarrow v$ and the firm does not earn any rent on the worker; this is the perfectly competitive labour market. In this situation, the worker would pay for general training, through receiving period 1 remuneration of $(1-\phi) v$ and period 1 remuneration of $g(\phi) v$. Second, there is imperfect competition if $F^{\prime}(0)<\infty$ and consequently $\omega_{1}<v$. We will show, in Proposition 3 below, that in this situation workers will not invest efficiently in general training. This is because their returns from any such investment are distorted through the fact that firms set wages oligopsonistically.

Equation (6) shows that the difference between the wage and the level of productivity depends on both the form of the retention function $F$, and on the training function $g$. Since $g^{\prime}(\phi)>0, g^{\prime \prime}(\phi)<0$, the second term in the square bracket of $(6)$ is decreasing in $\phi{ }^{14}$ It follows that the wage per augmented labour-unit will be closer to $v$ at high levels of training $\phi$.

Now consider the number of workers hired by each firm in the training sector given by equation (4). The number of workers hired is decreasing in $\omega_{1}$, which - as (6) shows is a function of the form of the retention function $F$ and the human capital acquisition

\footnotetext{
${ }^{13}$ Rewrite equation (3), using the industry equilibrium results, to obtain $2 R g(\phi)\left[(v-\omega) F^{\prime}(0)-F(0)\right]=$ $1-\phi$. Now substitute into this equation $R g^{\prime}(\phi)=\frac{1}{F(0)}$ - obtained from equation $(2)$ - in order to give equation (6) in the text.

${ }^{14}$ This is not a causal relationship as it only involves the equalisation of net rates of return to different forms of investment.
} 
function $g$. More workers are hired if the form of the retention function is such that profits are maximised at a low level of wages. This trade-off is shown in Figure 3.

\section{[Insert Figure 3 near here]}

Proposition 1 has shown that, in an imperfectly competitive labour market, the firm is able to extract rents from workers. These rents arise in our model because of workers' heterogeneous preferences or idiosyncratic match values. Although the firm wants to set wages to deter quitting, at the same time it also wants exploit any surplus from workers who are more likely to stay. The question now arises as to whether or not the firm might find it profitable to use these anticipated rents to finance general training. We therefore next consider sufficient conditions for the firm to finance general training, where the firm's choice of training intensity is denoted by $\phi^{c}$.

Proposition 2. In a frictional labour market in which the firm gets rent from the employment relation and there is some probability that the relation will continue into the second period, the firm will invest a positive amount in general training, that is $\phi^{c}>0$.

Proof: Expected profits from a given worker are $\tilde{P}=(1-\phi)(v-\omega)+F(x)(v-\omega) g(\phi)$, and note that $\tilde{P}^{\prime}(\phi)=\left[F(x) g^{\prime}(\phi)-1\right](v-\omega)$. Since $\left[F(x) g^{\prime}(0)-1\right]>0$ by assumption, $v-\omega>0$ implies $\tilde{P}^{\prime}(0)>0$.

The firm is here willing to finance its chosen level of general training because it augments workers' productivity in a multiplicative way. As shown in Booth and Zoega (2000), our formulation gives wage compression as defined by Acemoglu and Pischke (1999): increased training raises expected productivity - $F(x) g^{\prime}(0) v$ - by more than expected wages in the two periods - F(x) $\left.g^{\prime}(0)\right) \omega-(v-\omega)$ - as long as $F(x) g^{\prime}(0)>1$ and $v>\omega$.

In the following section we show that, compared to first best, the benchmark case developed in this section generates two types of market failure - (i) too few workers 
are hired into the training sector, and (ii) those workers who are hired receive too little training.

\section{First-Best Training Intensity and Hiring}

To show the welfare properties of both training decisions - the number of hires and the intensity of training once hired - we examine the outcome were a social planner to maximise the social returns from training, $S$.

Because training is general, the productivity of trained workers is the same in both firms in the industry. Suppose that a social planner maximises the social returns from training (that is, the value of total output produced by all $N$ trained workers - both those retained by any firm plus those who quit to work in the other firm - less the costs to society of training): ${ }^{15}$

$$
\max _{\{\phi, N\}} S=(1-\phi) v N+R g(\phi) v N-2 c\left(\frac{N}{2}\right)
$$

where $N=N_{1}+N_{2}$. The first-order condition for training intensity is:

$$
\phi: R g^{\prime}(\phi)=1
$$

which is analogous to that of Malcomson et al. (1997). This condition shows that the socially optimal level of training is such that the level of discounted future output created by spending more time training in Period 1 is equal to output sacrificed during training. This leads to our next proposition.

Proposition 3. In a labour market in which each firm sets training intensity unilaterally, each worker receives too little training relative to the first best.

Proof: Denote first-best training intensity as $\phi^{*}$ and training intensity set by the firm as $\phi^{c}$. Where training firms set training intensity unilaterally, the first order condition

\footnotetext{
${ }^{15}$ The costs to society of training also include the opportunity cost of production per worker in the alternative sector. This is set to zero throughout the paper for simplicity, as noted earlier.
} 
is given by (2), and thus $R F(x) g^{\prime}\left(\phi^{c}\right)=R g^{\prime}\left(\phi^{*}\right)=1$. It follows that $\phi^{*}>\phi^{c}$ given the concavity of $g(\phi)$ since $F(x)<1$.

The cause of the market failure is $F(0)<1$. Some workers leave their original employer even when wages are everywhere the same in the industry. If $F(0)=1$, the benchmark- and the first-best solutions would be the same. Thus it is the workers' heterogeneous preferences for firms' non-wage characteristics that drive the results. ${ }^{16}$

The socially optimal number of workers hired is given by the following equation, in which the marginal benefit to the economy from hiring a worker into the sector is equal to the marginal cost:

$$
N:[(1-\phi)+R g(\phi)] v=c^{\prime}\left(N_{1}\right)=c^{\prime}\left(N_{2}\right)
$$

This leads to our next proposition:

Proposition 4. In a labour market in which each firm sets training intensity unilaterally, the number of workers hired is smaller than the social optimum.

Proof: A comparison of equations (9) and (4) reveals that, were the social returns to training in the sector maximized rather than firms individually maximizing expected profits, the number of workers trained would be higher $\left(N^{*}>N^{c}\right)$. Intuitively, this is because the social planner does not discount by the retention probability, whereas each individual firm does. ${ }^{17}$ Thus too few workers are hired into the training sector.

\section{Training Subsidies or Minimum Wages}

We next address the question of whether or not the social optimal level of training intensity can be attained under different institutional arrangements for setting wages and training intensity.

\footnotetext{
${ }^{16}$ Since $g^{\prime}\left(\phi^{*}\right)=1 / R$, we also know from the properties of the training function that $\phi^{*}<1$. It is optimal for trainees to spend some time producing in Period 1.

${ }^{17}$ Recall that the social planner sets the opportunity cost of labour equal to its true value of zero, and hence this does not enter (7) or (9).
} 
Perhaps the most direct way of achieving the social optimum is to give firms a subsidy which is based on the level of training that they provide. From equations (1), (2), (7) and (8) we can derive the required form for this subsidy. When the following function is added to the right-hand side of equation (1), then

$$
h(\phi)=R(1-F) g(\phi)(v-\omega)
$$

and it follows that equations (2) and (8) will be identical. This implies that the firms would provide workers with the socially-optimal level of training. Note that the hiring subsidy is increasing in the discount factor $R$, post-training productivity $g(\phi)$, and the markup of productivity over wages $(v-\omega)$.

It is also clear from our model that the introduction of a minimum wage equal to $v$ would remove the training inefficiency and would provide workers with the right incentives to invest in general training. From equation (6), if $\omega_{1}=v$ the firm does not earn any rent on the worker (this is wage rate in the perfectly competitive labour market) and therefore there is no incentive for the firm to finance transferable training. It would therefore be up to the worker to finance and decide on the level of training. In this situation, the worker would be willing to pay for general training through receiving period 1 remuneration of $(1-\phi) v$ and would receive the full returns to training investments through period 2 remuneration of $g(\phi) v$.

However, minimum wages are typically applied universally and not sector-by-sector. ${ }^{18}$ Since investment in general training varies considerably across different industries, it is unrealistic to suppose that our model can be used to justify a uniform minimum wage for all sectors of the economy. What our model does suggest, however, is an economic rationale for industry-level minimum wages. It also suggests an economic rationale for appropriate training subsidies to firms.

Microecometric studies of the relationship between training and minimum wages so far all using US data - compare the training received by a treatment group of

\footnotetext{
${ }^{18} \mathrm{It}$ is interesting that industry-level minimum wages were phased out in Britain in the early $1990 \mathrm{~s}$ and a national minimum wage introduced in 1999.
} 
workers directly affected by the minimum wage to that received by a control group of unaffected workers. These studies produce mixed evidence. Neumark and Wascher (2001) reported evidence that workers subject to a minimum wage received less training, whilst Grossberg and Sicilian (1999) and Acemoglu and Pischke (2001) found no clear evidence that minimum wages affected training either way. It remains to be seen what the empirical evidence is for other countries.

There is another way of giving workers the responsibility for deciding on the level of training. Workers can form labour unions that assume the power to decide on the level of training as well as wages. We now consider two alternative institutions that might affect training efficiency: first, an industry-wide labour union with the power to set wages and training intensity unilaterally; and second, two firm-specific monopoly unions.

\section{Unions to the Rescue?}

\subsection{An Industry-wide Union}

Consider an industry-wide monopoly union, which decides both wages and the intensity of training in order to maximise the returns to its membership from training. This differs from the two cases outlined in the previous sections, since here the union sets sector-wide wages and training intensity, but each firm retains the right to determine its number of trainees. ${ }^{19}$ At the start of Period 1, each firm decides how many workers to hire and train. After these workers have been hired, the industry-wide union forms, and its membership comprises all $N$ workers in the sector. The union then makes a take-it-or-leave-it wage and training intensity offer to the two firms. We assume that the union sets the wage such that all union members remain employed. For this reason it is concerned about the

\footnotetext{
${ }^{19}$ We differ from Acemoglu and Pischke (1999) in a number of respects. First, we allow both training and wages to be the subject of union negotiation. Second, we model the remuneration of workers during training as well as after training. Third, we investigate the degree to which the outcome varies depending on the level at which bargaining occurs.
} 
cost of training the marginal member.

The union maximises the expected utility $U$ of its representative member with respect to wages and training intensity. ${ }^{20}$ We assume that the utility functions are concave in wage income, $u(\omega), u^{\prime}>0, u^{\prime \prime}<0$. The problem is to:

$$
\max _{\{\phi, \omega\}} U=(1-\phi) u(\omega)+R g(\phi) u(\omega)
$$

subject to

$$
P_{1}=P_{2}=0
$$

where the profit functions are defined in equation (1). Since the union's available surplus is declining in firms' profits, it will always choose as a constraint the lowest level of profits commensurate with ensuring the survival of the firm (i.e. with making nonnegative profits $){ }^{21}$ For this reason, in (12) each firm's profit from employing the marginal member net of training costs is set equal to zero. Note that $F(0)=\frac{1}{2}$ in the case of an industry-wide union. The union cannot affect the retention probability because it only sets one level of wages for the industry. Notice also that $\partial P_{1} / \partial \phi=\partial P_{2} / \partial \phi=$ $(v-\omega)\left(\frac{N}{2}\right)\left[R g^{\prime}(\phi)-1\right]$, using the fact that $N_{1}=N_{2}=\frac{N}{2}$ and $\omega_{1}=\omega_{2}$. The first-order conditions are:

$$
\begin{aligned}
& \phi:\left[R g^{\prime}(\phi)-1\right]\left[u(\omega)+\left(\lambda_{1}+\lambda_{2}\right)(v-\omega) \frac{N}{2}\right]=0 \\
& \omega:(1-\phi) u^{\prime}(\omega)+R g(\phi) u^{\prime}(\omega)-\left(\lambda_{1}+\lambda_{2}\right)\left[(1-\phi) \frac{N}{2}+R g(\phi) \frac{N}{2}\right]=0 \\
& \lambda: P_{1}=P_{2}=0
\end{aligned}
$$

\footnotetext{
${ }^{20}$ The retention rate does not enter equation (10) because the worker can transfer all of his or her productivity between the two firms, which are identical by assumption.

${ }^{21}$ The firm has to make non-negative profits otherwise it will not hire the marginal worker, but the monopoly union sets $\phi$ and $\omega$ so that the firm makes zero profits (since union surplus will be reduced if profits are strictly positive).
} 
The variable $\lambda_{i}(i=1,2)$, the Lagrangian multiplier in the constrained maximisation problem of (11), denotes the shadow price of the profit constraint, and $F(0)=1 / 2 .{ }^{22}$ This brings us to an important proposition.

Proposition 5. When an industry-wide trade union sets training intensity and wages, training intensity is at the efficient level.

Proof: In equation (13), it is straightforward to see that the second expression in square brackets has to be positive, and thus the first-order condition can only be satisfied when $R g^{\prime}(\phi)=1$. This is the first-best outcome given in equation (8).

Intuitively, the union is internalising one of the externalities that arises from the fact that the training firm does not benefit from the higher productivity of workers who quit. Industry-wide labour unions raise the intensity of training because their discount factor is higher than that of firms: workers own their human capital while firms can only hire it. $^{23}$

Proposition 5 survives an alternative specification of the union maximand. In the algebra above, we assumed that the union sets the wage such that all union members remain employed. An alternative maximand might be $\max _{\{\phi, \omega\}} U=\frac{n(\omega)}{N}(1-\phi) u(\omega)+$ $\left[1-\frac{n(\omega)}{N}\right] R g(\phi) u(\omega)$ as per the usual monopoly union model, in which $\frac{n(\omega)}{N}$ denotes the proportion of initially hired workers actually employed in the sector after the union forms, and $n^{\prime}(\omega)<0, n^{\prime \prime}(\omega)=0$. It is straightforward to show that, in such a model, training intensity remains at its efficient level (although wages will now be higher and there will be some unemployment of new hires). The reason for this is that the industrylevel union always discounts the second period by $R$ unlike the individual firms that discount by $R F(\cdot)$.

\footnotetext{
${ }^{22}$ The second-order condition is satisfied so that the determinant of the bordered Hessian is positive.

${ }^{23}$ Similar reasoning would lead us to think that firms should pay for the maintenance of machinery, not workers, as they own the machines while workers can only use them while employed and hence have a lower discount rate.
} 


\subsection{A Firm-level Union}

Now consider the case of firm-specific unions. Suppose there are two unions in the industry, one corresponding to each firm. At the start of Period 1, each firm decides how many workers to hire and train. After these workers have been hired, the two firmspecific unions form and the membership of each union comprises all workers hired into each firm. Each firm-specific union then makes a take-it-or-leave-it wage and training intensity offer to the two firms. We assume that the union sets the wage such that all union members in the firm become employed. As workers cannot quit in Period 1 by assumption, they will never work for the alternative firm in that period. However, with probability $[1-F(x)]$ the trained worker may leave the training firm at the beginning of Period 2 to work for the alternative firm. Because training is entirely general, the productivity of workers is the same in both firms in the industry. The objective function of the Firm 1 union can be written as:

$$
\max _{\left\{\phi_{1}, \omega_{1}\right\}} U_{1}=\left(1-\phi_{1}\right) u\left(\omega_{1}\right)+R F(x) g\left(\phi_{1}\right) u\left(\omega_{1}\right)
$$

subject to

$$
P_{1}=0
$$

where $\phi_{1}$ is the level of training and $\omega_{1}$ the wage rate in Firm 1 . The first term in equation (16) gives the utility of the representative union member for the time spent producing in Period 1 and the second term gives the expected discounted utility for working for the training firm in Period 2.

The first-order conditions give the solution for $\omega_{1}, \phi_{1}$ and the Lagrange multiplier $\lambda_{1}$;

$$
\begin{aligned}
& \phi_{1}:\left(R F(x) g^{\prime}\left(\phi_{1}\right)-1\right)\left[u\left(\omega_{1}\right)+\lambda\left(v-\omega_{1}\right) N_{1}\right]=0 \\
& \omega_{1}:\left(1-\phi_{1}\right) u^{\prime}\left(\omega_{1}\right)+R F(x) g\left(\phi_{1}\right) u^{\prime}\left(\omega_{1}\right) \\
& +R F^{\prime}(x) g\left(\phi_{1}\right) u\left(\omega_{1}\right)-\lambda \Psi=0
\end{aligned}
$$


where $\Psi=\left[\left(1-\phi_{1}\right) N_{1}-R F^{\prime}(x)\left(v-\omega_{1}\right) \Lambda+R F(x) g\left(\phi_{1}\right) \Lambda\right]$ and $\Lambda=g\left(\phi_{1}\right) N_{1}+$ $g\left(\phi_{2}\right) N_{2}$, and

$$
\lambda: P_{1}=0
$$

With two identical firms in symmetric equilibrium, the first-order conditions differ from those for the industry union. Most importantly, the firm-specific union does not reach the social optimum with respect to training. The key reason for this is that the function $F$ appears in the union maximand for the firm-specific union. This result depends crucially on unions not caring about the utility level of ex-members.

The equations also show that the firm-level union may set slightly higher wages than the industry-level one because it calculates that there is an indirect positive effect on profits when higher wages reduce quits and raise the number of workers poached. By raising the employer's wages, the firm-level union will ensure that it retains and attracts more workers at the beginning of Period 2. However, there is an offsetting effect in the union's objective function: A union that cares only about its members' welfare and not about the welfare of its ex-members — as is the case here (see equation (16)) — will not press as hard for wage increases because the marginal benefit of doing so is smaller due to $F(x)<1$. A comparison of equations (14) and (19) reveals that the first effect dominates if $F^{\prime}(x)>1-F(x)$, quits are sufficiently sensitive to wage increases.

Now suppose there is only one firm-specific union in the industry, so that the wage in the unionised firm is higher than in the non-unionised one. From equations (18)-(20) it should be clear that the retention probability goes up in the unionised firm. The union will as a result ask for increased training. We conclude that unions can also raise training if they affect relative wages and quit rates. But the downside is obvious: quits must go up in the non-unionised firms, and so also must the quitting externality, which reduces training further. On balance, we cannot say whether the average level of training will be higher in the sector than in a non-unionised sector since training goes up in the unionised firm and goes down in the non-unionised firm. 


\subsection{Empirical Evidence}

Microeconometric studies typically show that unionised workers are significantly more likely to receive work-related training than non-unionised ones (see for example Booth, 1991; Lynch, 1992; Barron, Berger and Black, 1997; Green, Machin and Wilkinson, 1999; Booth, Francesconi and Zoega, 2001). Some earlier US-based studies have, however, found a negative correlation (see Duncan and Stafford, 1980; Mincer, 1993; Lillard and Tan, 1992; Barron, Fuess and Loewenstein, 1987).

This mixture of evidence presents a challenge to the competitive labour market model according to which unions should always be associated with a lower general training incidence and intensity. However, these studies are typically based on individual-level data, and hence there is no means of distinguishing the level at which bargaining takes place.

In order to motivate our discussion further we next use cross-country aggregate data for European countries to estimate the relationship between training and unions. The dependent variable is the percentage of country's workforce (aged 25 to 54 ) in training in the 1990s and this is regressed on union coverage and union coordination. Coordination is defined as either formal or informal co-ordination between independent unions and employers frequently at the industry-level. (This should not be confused with centralization; for discussion of these concepts see Boeri et al, 2001:91). Our results are given in Table $1 .{ }^{24}$

\footnotetext{
${ }^{24}$ The data are for the twelve European countries for which we could obtain coverage data (Sweden, Finland, Norway, Denmark, Austria, Germany Belgium, Netherlands, France, Spain, Portugal). The dependent variable is the percentage of a country's workforce aged 25-54 years in work-related training in the 1990s (OECD,1999: Table 3.2). The explanatory variables are the proportion of a country's workforce covered by union wage bargaining (from Boeri et al (2001: 80) and the degree of union coordination ranging from 1 (uncoordinated) to 3 (highly coordinated) and ontained from Layard and Nickell (1999).
} 
Table 1: The Correlation between Training and Union Coverage and Co-ordination, $1990 \mathrm{~s}$

\begin{tabular}{lrrr}
\hline Variable & Coefficient & t-statistic & Mean \\
\hline Constant & 8.52 & 2.00 & 1.00 \\
Coverage & -26.38 & 2.37 & 70.67 \\
Coordination & 5.13 & 1.79 & 2.25 \\
Adjusted $R^{2}$ & 0.302 & & \\
\hline
\end{tabular}

We find that training is declining in union coverage but increasing in union coordination, a finding that is consistent with our results earlier in this section.

\section{Conclusions}

We have found that, in a model in which the amount of general training is endogenous and wages are set oligopsonistically, workers will not invest efficiently in general training because they will not receive the full returns. However, since firms gain rents from the employment relationship, they may be willing to finance general training although not at the efficient level. In such a situation, we showed that there are several institutions that might help eliminate the inefficiency. First, an industry-wide minimum wage can provide workers with the right incentives to invest in general training. Alternatively a training subsidy to firms can also achieve first best. Second, we showed that a monopoly union has the standard adverse effects on employment - by raising wages, and making firms raise the intensity of training, the number of workers trained is reduced. But we also obtained a new result: unions can help reduce and sometimes overcome a market failure in the provision of on-the-job training.

When training is general to an industry, firms choose a sub-optimal level of such training, since they realise that workers would take with them any human capital when 
leaving for other firms in the industry. But the human capital is not lost to society, so a market failure arises: private discount rates are higher than social ones. Unions can remedy the market failure in two ways. First, if an industry-wide union has a direct say in the training decision and maximises the utility of a representative worker, it will choose the efficient level of training intensity (as its discount rate is equal to the social discount rate). The industry-wide union internalises one of the externalities arising from the fact that the training firm does not benefit from the higher productivity of workers who quit. ${ }^{25}$ Second, firm-specific unions can reduce the quitting externality in their firms by raising relative wages, hence reducing quits and the employer's discount rates. While the second effect is known in the union literature, the first effect is new.

\footnotetext{
${ }^{25}$ But since investment in general training varies considerably across sectors of the economy and so too do stochastic quits, it is unrealistic to suppose that our market failure rationale for union bargaining over wages and training can be used to justify centralised wage and training determination for all sectors of the economy.
} 


\section{Appendix A}

\section{Investigation of equilibrium wages and training when wages are set separately in each period}

\section{Period 2}

Proceed by backward induction. Suppose the firm sets $\omega_{t+1}$ at the start of the $2^{\text {nd }}$ period before workers decide to quit. Firms want to deter quitting and to exploit any surplus from the workers who are more likely to stay given their stochastic preferences. The firm does not know the preferences of individual workers, only that a proportion of them will stay. Thus it cannot act as a perfectly discriminating monopsonist. (This is done for expositional ease, and does not affect the substance of the results. The firm might do this because it is costly/there is moral hazard in verifying workers' outside opportunities, family circumstances, etc.). Then the firm:

$$
\max _{\left\{\omega_{1}\right\}} P_{t+1}=N_{1} F(x) g\left(\phi_{1}\right)\left(v-\omega_{t+1}\right)+N_{2} F(x) g\left(\phi_{2}\right)\left(v-\omega_{t+1}\right)
$$

and the first order condition is

$$
\begin{aligned}
& N_{1}\left[F^{\prime}(x) g\left(\phi_{1}\right)\left(v-\omega_{t+1}\right)-F(x) g\left(\phi_{1}\right)\right] \\
& +N_{2}\left[F^{\prime}(x) g\left(\phi_{2}\right)\left(v-\omega_{t+1}\right)-F(x) g\left(\phi_{2}\right)\right]=0 .
\end{aligned}
$$

By the symmetry assumption, both firms will behave the same way, so $\phi_{1}=\phi_{2}$ and $N_{1}=N_{2}$. Thus the first order condition becomes:

$$
2 F^{\prime}(x) g(\phi)\left(v-\omega_{t+1}\right)-2 F(x) g(\phi)=0,
$$

which upon rearrangement yields:

$$
\omega_{t+1}=v-\frac{F}{F^{\prime}}=v-\kappa
$$


Here the firm is taking advantage of the fact that workers are differentiated by preferences for working in a particular location. Worker remuneration in Period 2 is $\omega_{t+1} g(\phi)=$ $(v-\kappa) g(\phi)$ where $\phi$ is determined in the first period (see below).

We can now write optimally chosen Period 2 profits $P_{t+1}^{*}$ as:

$$
P_{t+1}^{*}\left(\omega_{t+1}^{*} ; N_{1}, \phi, \kappa\right)=N_{1} F(x) g\left(\phi_{1}\right) \kappa+N_{2} F(x) g\left(\phi_{2}\right) \kappa .
$$

In the neighbourhood of the optimum $\frac{\partial P_{t+1}^{*}}{\partial N_{1}}>0 ; \frac{\partial P_{t+1}^{*}}{\partial \phi}>0$ and $\frac{\partial P_{t+1}^{*}}{\partial \kappa}>0$.

\section{Period 1}

Now consider Period 1. The firm knows ex ante how it will behave to deter quitting in Period 2 as above, and uses this in conjunction with the incentive compatibility constraint when it sets its Period 1 choice variables. The incentive compatibility constraint is given in $(27)$ below. It represents the fact that - to induce workers to participate in the training sector - they must receive at least as much utility as they would get in the alternative sector. The Period 1 profits function is given by:

$$
\max _{\left\{\phi_{1}, \omega_{1}\right\}} P_{1}=N_{1}\left(1-\phi_{1}\right)\left(v-\omega_{t}\right)+R P_{t+1}^{*}-c\left(N_{1}\right)
$$

subject to

$$
\omega_{t}(1-\phi)+R \omega_{t+1} g(\phi) \geq \bar{u} \equiv(1+R) b
$$

where $\bar{u}$ is alternative utility, and $\omega_{t}$ and $\omega_{t+1}$ represent first and second period remuneration respectively (in the sector). This can be thought of as the first and second period 'wage per efficiency unit'. Rearrange (27) to obtain: ${ }^{26}$

$$
w_{t} \equiv h\left(\phi, w_{t+1}\right)=\frac{\left[\bar{u}-R g(\phi) w_{t+1}\right]}{1-\phi}
$$

\footnotetext{
${ }^{26}$ In principle we could express the IC constraint as:

$$
\omega_{t+1}=\frac{\bar{u}-\omega_{t}(1-\phi)}{g(\phi)}
$$

and substitute this directly into the firm's Period 1 maximand, and solve for $\omega_{t}$ and $\phi$. However, the firm could renege on this contract at the start of Period 2, when workers have established their preferences for staying at a particular firm. The contract represented by (28) avoids this hold-up problem.
} 
Notice that (using (24)):

$$
\frac{\partial w_{t}}{\partial \phi} \equiv \frac{\partial h}{\partial \phi}=\frac{\left[\bar{u}-R g(\phi)(v-\kappa)-R g^{\prime}(\phi)(v-\kappa)(1-\phi)\right]}{(1-\phi)^{2}} .
$$

Differentiation of (25) with respect to $\phi$ yields:

$$
\begin{aligned}
& -(v-h)-(1-\phi) \frac{\partial h}{\partial \phi}+R F(x) g^{\prime}(\phi) \kappa=0 \\
& {\left[R g^{\prime}(\phi)-1-\frac{\kappa}{v}(1-F)\right]=1 .}
\end{aligned}
$$

Notice that if $F=1$, or if $\kappa=0$, then (31) collapses to the first best solution of $R g^{\prime}=1$. Intuitively this is because it is only the lack of competition induced by the stochastic quits that provides any surplus for training firms - otherwise they would simply not train.

\section{Appendix B}

\section{Proof of Existence and Uniqueness of Symmetric Equilibrium for the Industry}

Profits for Firm 1 can be written as:

$$
\begin{aligned}
P_{1} & =\left(1-\phi_{1}\right)\left(v-\omega_{1}\right) N_{1}+R g\left(\phi_{1}\right)\left(v-\omega_{1}\right) F(x) N_{1} \\
& +R g\left(\phi_{2}\right)\left(v-\omega_{1}\right) F(x) N_{2}-c\left(N_{1}\right) .
\end{aligned}
$$

Maximisation of (32) with respect to training intensity $\phi$ and wages $\omega$ respectively gives:

$$
\begin{aligned}
& R F(x) g^{\prime}\left(\phi_{1}\right)=1 \\
& {\left[R g\left(\phi_{1}\right) N_{1}+R g\left(\phi_{2}\right) N_{2}\right]\left\{\left(v-\omega_{1}\right) F^{\prime}(x)-F(x)\right\}=\left(1-\phi_{1}\right) N_{1} .}
\end{aligned}
$$


The analogous expected profit equation for Firm 2 is:

$$
\begin{aligned}
P_{2} & =\left(1-\phi_{2}\right)\left(v-\omega_{2}\right) N_{2}+R g\left(\phi_{2}\right)\left(v-\omega_{2}\right) F(-x) N_{2} \\
& +R g\left(\phi_{1}\right)\left(v-\omega_{2}\right) F(-x) N_{1} .
\end{aligned}
$$

The first order conditions of Firm 2 are:

$$
\begin{aligned}
& R F(-x) g^{\prime}\left(\phi_{2}\right)=1 \\
& {\left[R g\left(\phi_{1}\right) N_{1}+R g\left(\phi_{2}\right) N_{2}\right]\left\{\left(v-\omega_{2}\right) F^{\prime}(-x)-F(-x)\right\}=\left(1-\phi_{2}\right) N_{2} .}
\end{aligned}
$$

Now subtract (37) from (34) to obtain:

$$
\frac{\left(1-\phi_{2}\right) N_{2}-\left(1-\phi_{1}\right) N_{1}}{R g\left(\phi_{2}\right) N_{2}+R g\left(\phi_{1}\right) N_{1}}=\left[x F^{\prime}(x)+2 F(x)-1\right] .
$$

Rearrange (38) and define the following function, assumed to be continuous from continuity of the underlying functions:

$$
\Psi(x)=\left[x F^{\prime}(x)+2 F(x)-1\right]-\left[\frac{\left(1-\phi_{2}\right) N_{2}-\left(1-\phi_{1}\right) N_{1}}{R g\left(\phi_{2}\right) N_{2}+R g\left(\phi_{1}\right) N_{1}}\right]
$$

We now show existence of an industry equilibrium by showing that equation (39) only holds for $x=0$, that is $\omega_{1}=\omega_{2}$.

Case 1: $x \rightarrow \infty$

From the properties of the retention function, $F(x)$, we know that as $x \equiv\left(\omega_{1}-\omega_{2}\right) \rightarrow$ $\infty, F(x) \rightarrow 1$ and $F^{\prime}(x) \rightarrow 0$. Equation (39) now becomes

$$
1+\frac{1-\phi_{1}}{R g\left(\phi_{1}\right)}>0
$$

since $N_{2}=0$ when $x \rightarrow \infty$. Hence $\Psi(x)>0$ as $x \rightarrow \infty$.

Case 2: $\omega_{1}=\omega_{2}$

Here $F(x)=1 / 2$ and the first term in (39) disappears. The equation can only hold if the second term is equal to zero also. Since $x=0$ we can equate (33) and (36) to obtain $\phi_{1}=\phi_{2}$. Thus (39) only holds if $N_{1}=N_{2}$. This implies $\Psi(x)=0$ if $x=0$. 
Case 3: $x \rightarrow-\infty$

As $x \rightarrow-\infty, F(x) \rightarrow 0$ and $F^{\prime}(x) \rightarrow 0$. Equation $(39)$ now reads as

$$
-1-\frac{1-\phi_{2}}{R g\left(\phi_{2}\right)}<0
$$

To guarantee uniqueness of the symmetric equilibrium $\omega_{1}=\omega_{2}$, note that

$$
\Psi^{\prime}(x)=3 F^{\prime}(x)+x F^{\prime \prime}(x) .
$$

Hence $\Psi(x)<0$ as $x \rightarrow \infty$.

A sufficient condition for uniqueness of solution $\omega_{1}=\omega_{2}$ is $3 F^{\prime}(x)>-x F^{\prime \prime}(x)$ since $x F^{\prime}(x)<0, \forall x$. 


\section{References}

[1] Acemoglu, Daron and Jörn-Steffen Pischke (1998) "Why do Firms Train? Theory and Evidence", Quarterly Journal of Economics, 113(1), pp. 79-119.

[2] Acemoglu, Daron and Jörn-Steffen Pischke (1999) "The Structure of Wages and Investment in General Training", Journal of Political Economy, 107(3), pp. 539572.

[3] Acemoglu, Daron and Jörn-Steffen Pischke (2001) "Minimum Wages and On-the-job Training", mimeo, London School of Economics.

[4] Barron, John M., Mark C. Berger and Dan A. Black (1997) On-the-Job Training, W.E. Upjohn Institute for Employment Research.

[5] Barron, John M, Fuess, Scott M, Jr, and Mark A Loewenstein (1987) "Further Analysis of the Effect of Unions on Training, Union Wages, Temporary Layoffs, and Seniority", Journal of Political Economy, 95(3), pp. 632-640.

[6] Becker, Gary (1964) Human Capital, Chicago: The University of Chicago Press.

[7] Bhaskar V., Alan Manning and Ted To (2002) "Oligopsony and Monopsonistic Competition in Labour Markets", The Journal of Economic Perspectives, 16(2), pp. $155-174$.

[8] Bhaskar V. and Ted To (2001) "Oligopsony and the Distribution of Wages," forthcoming The European Economic Review.

[9] Boeri, T, A Brugiavini and L Calmfors (eds) (2001) The Role of Unions in the Twenty-first Century, Oxford: Oxford University Press.

[10] Booth, Alison L. (1991) "Job-related Formal Training: Who Receives It And What Is It Worth?", Oxford Bulletin of Economics and Statistics, 53, pp. 281-294. 
[11] Booth, Alison L. and Monojit Chatterji (1998) "Unions and Efficient Training", The Economic Journal, 108, pp. 328-343.

[12] Booth, Alison L., Marco Francesconi and Gylfi Zoega (2001) "Unions, Training and Wages: Evidence for British Men", mimeo, University of Essex.

[13] Booth, Alison L. and Gylfi Zoega (1999) "Do Quits Cause Under-training?", Oxford Economic Papers, 51, pp. 374-386.

[14] Booth, Alison L. and Gylfi Zoega (2000) "Is Wage Compression a Necessary Condition for Firm-financed General Training? A Comment on Acemoglu and Pischke", Discussion paper \# 2/00 Birkbeck College.

[15] Calmfors L and J Driffill (1988) "Bargaining Structure, Corporatism and Macroeconomic Performance," Economic Policy, 6, pp. 13-62.

[16] Chang, Chun and Yijiang Wang (1996) "Human Capital Investment under Asymmetric Information: The Pigovian Conjecture Revisited", Journal of Labor Economics, 14, pp. 505-519.

[17] Chatterji, Monojit (2000) "Trade Union Power and Economic Efficiency", mimeo, University of Dundee, Economics Department.

[18] Dowrick, S. (1989) "Union-Oligopoly Bargaining", The Economic Journal, 99, pp. $1123-42$.

[19] Duncan, Greg J., and Frank P. Stafford (1980) "Do Union Members Receive Compensating Differentials?", American Economic Review, 70(3), pp. 355-371.

[20] Eguchi, Kyota (2002) "Unions as Commitment Devices", Journal of Economic Behavior and Organisation, 47, pp. 407-421. 
[21] Flanagan, Robert J. (1999) "Macroeconomic Performance and Collective Bargaining: An International Perspective", Journal of Economic Literature, 37, pp. 11501175 .

[22] Green, Francis, Stephen Machin, and David Wilkinson (1999) "Trade unions and training practices in British workplaces", Industrial and Labor Relations Review, 52(2), pp. 179-195.

[23] Grossberg Adam J. and Paul Sicilian (1999) "Minimum Wages, On-the-job Training and Wage Growth", Southern Economic Journal, 65(1).

[24] Layard Richard and Stephen J. Nickell, (1999) "Labor Market Institutions and Economic Performance," in Orley Ashenfelter and David Card (eds.) Handbook of Labor Economics Vol. 3, Amsterdam: North-Holland.

[25] Lillard, Lee A. and Hong Tan (1992) "Private Sector Training: Who Gets it and What are its Effects?", Research in Labor Economics, 13.

[26] Lynch, Lisa M. (1992) "Private Sector Training and the Earnings of Young Workers", American Economic Review, 81, pp. 299-312.

[27] Mahnkopf B (1992) “The 'Skill-oriented' Strategies of German Trade Unions: Their Impact on Efficiency and Equality Objectives", The British Journal of Industrial Relations 30(1), pp. 61-81.

[28] Malcomson, James M., James W. Maw and Barry McCormick (1997), "General Training by Firms, Apprentice Contracts, and Public Policy", forthcoming The European Economic Review.

[29] McCue, K. and W.R. Reed (1996) “New Empirical Evidence on Worker Willingness to Pay for Job Attributes", Southern Economic Journal, 62(3), 647-653. 
[30] Mincer, Jacob (1983) "Union Effects: Wages, Turnover, and Job Training", in Joseph D Reid, Jr. (ed.), Research in Labor Economics, Supplement 2 (New Approaches to Labor Unions), Greenwich, CT: JAI Press.

[31] Neumark David and William Wascher (2001) "Minimum Wages and Training Revisited", Journal of Labor Economics, 19(3), pp. 563-595.

[32] OECD (1995) The Jobs Study, Paris.

[33] OECD (1999) Employment Outlook, Paris, June.

[34] Stevens, Margaret (1994) "A Theoretical Model of On-the-job Training with Imperfect Competition", Oxford Economic Papers, 46, pp. 537-562.

[35] Stevens, Margaret (1996) "Transferable Training and Poaching Externalities", in Alison L. Booth and Dennis J. Snower (eds.) Acquiring Skills, Cambridge: Cambridge University Press.

[36] Streeck W (1989) "Skills and the Limits of Neo-Liberalism: The Enterprise of the Future as a Place of Learning", Work, Employment and Society, 3(1), 89-104. 


\section{IZA Discussion Papers}

\begin{tabular}{|c|c|c|c|c|}
\hline No. & Author(s) & Title & Area & Date \\
\hline 601 & $\begin{array}{l}\text { Š. Jurajda } \\
\text { K. Terrell }\end{array}$ & $\begin{array}{l}\text { What Drives the Speed of Job Reallocation } \\
\text { during Episodes of Massive Adjustment? }\end{array}$ & 5 & $10 / 02$ \\
\hline 602 & L. Locher & Migration in the Soviet Successor States & 2 & $10 / 02$ \\
\hline 603 & $\begin{array}{l}\text { T. Andrén } \\
\text { B. Gustafsson }\end{array}$ & $\begin{array}{l}\text { Income Effects from Labor Market Training } \\
\text { Programs in Sweden During the 80's and 90's }\end{array}$ & 2 & $10 / 02$ \\
\hline 604 & $\begin{array}{l}\text { S. P. Jenkins } \\
\text { C. Schluter }\end{array}$ & $\begin{array}{l}\text { The Effect of Family Income during Childhood on } \\
\text { Later-Life Attainment: Evidence from Germany }\end{array}$ & 5 & $10 / 02$ \\
\hline 605 & C. Grund & $\begin{array}{l}\text { The Wage Policy of Firms - Comparative } \\
\text { Evidence for the U.S. and Germany from } \\
\text { Personnel Data }\end{array}$ & 5 & $10 / 02$ \\
\hline 606 & $\begin{array}{l}\text { M. Gerfin } \\
\text { M. Lechner } \\
\text { H. Steiger }\end{array}$ & $\begin{array}{l}\text { Does Subsidised Temporary Employment Get } \\
\text { the Unemployed Back to Work? An Econometric } \\
\text { Analysis of Two Different Schemes }\end{array}$ & 3 & $10 / 02$ \\
\hline 607 & Y. Zenou & How Do Firms Redline Workers? & 5 & $10 / 02$ \\
\hline 608 & G. Saint-Paul & $\begin{array}{l}\text { Economic Aspects of Human Cloning and } \\
\text { Reprogenetics }\end{array}$ & 3 & $10 / 02$ \\
\hline 609 & G. Saint-Paul & Cognitive Ability and Paternalism & 3 & $10 / 02$ \\
\hline 610 & A. Heitmueller & $\begin{array}{l}\text { Unemployment Benefits, Risk Aversion, and } \\
\text { Migration Incentives }\end{array}$ & 4 & $10 / 02$ \\
\hline 611 & G. Saint-Paul & $\begin{array}{l}\text { Some Thoughts on Macroeconomic Fluctuations } \\
\text { and the Timing of Labor Market Reform }\end{array}$ & 3 & $10 / 02$ \\
\hline 612 & $\begin{array}{l}\text { J. J. Dolado } \\
\text { M. Jansen } \\
\text { J. F. Jimeno }\end{array}$ & $\begin{array}{l}\text { A Matching Model of Crowding-Out and On-the- } \\
\text { Job Search (with an Application to Spain) }\end{array}$ & 2 & $10 / 02$ \\
\hline 613 & $\begin{array}{l}\text { P. Kuhn } \\
\text { M. Skuterud }\end{array}$ & $\begin{array}{l}\text { Internet Job Search and Unemployment } \\
\text { Durations }\end{array}$ & 5 & $10 / 02$ \\
\hline 614 & M. Pannenberg & $\begin{array}{l}\text { Long-Term Effects of Unpaid Overtime: } \\
\text { Evidence for West Germany }\end{array}$ & 1 & $10 / 02$ \\
\hline 615 & W. Koeniger & $\begin{array}{l}\text { The Dynamics of Market Insurance, Insurable } \\
\text { Assets, and Wealth Accumulation }\end{array}$ & 3 & $10 / 02$ \\
\hline 616 & $\begin{array}{l}\text { R. Hujer } \\
\text { U. Blien } \\
\text { M. Caliendo } \\
\text { C. Zeiss }\end{array}$ & $\begin{array}{l}\text { Macroeconometric Evaluation of Active Labour } \\
\text { Market Policies in Germany - A Dynamic Panel } \\
\text { Approach Using Regional Data }\end{array}$ & 6 & $10 / 02$ \\
\hline 617 & $\begin{array}{l}\text { L. Magee } \\
\text { M. R. Veall }\end{array}$ & $\begin{array}{l}\text { Allocating Awards Across Noncomparable } \\
\text { Categories }\end{array}$ & 1 & $10 / 02$ \\
\hline 618 & $\begin{array}{l}\text { A. L. Booth } \\
\text { M. Francesconi } \\
\text { G. Zoega }\end{array}$ & $\begin{array}{l}\text { Oligopsony, Institutions and the Efficiency of } \\
\text { General Training }\end{array}$ & 6 & $10 / 02$ \\
\hline
\end{tabular}

An updated list of IZA Discussion Papers is available on the center's homepage www.iza.org. 